\title{
Differential gene expression in Litopenaeus vannamei shrimp in response to diet changes
}

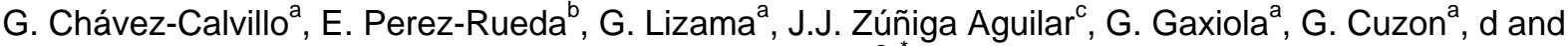 \\ L. Arena-Ortiz ${ }^{a}$ * \\ a Unidad Multidisciplinaria de Docencia e Investigación, Sisal Facultad de Ciencias, Sisal, Yucatán, UNAM, \\ México \\ ${ }^{\mathrm{b}}$ Instituto de Biotecnología UNAM, México \\ c Centro de Investigación Científica de Yucatán, México

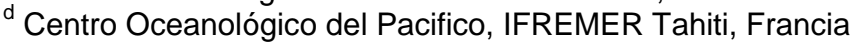 \\ *: Corresponding author : L. Arena-Ortiz, Tel./fax: +52 55988 931007x7144, email address : \\ leticia.arena@ciencias.unam.mx
}

\begin{abstract}
:
We evaluated changes in gene expression of Litopenaeus vannamei shrimp in response to a change in diet by comparing specimens which were fed with an animal protein diet against those which underwent a change from an animal protein diet to a plant protein diet. In addition, we also compared specimens which were fed with a plant protein diet with another group which underwent a change from plant to animal protein diet. Results showed that, in the case of hepatopancreas tissue, a total of six genes were differentially expressed and exhibited a high degree of homology with sequences which codify for proteins related to metabolism, transcription regulation, and rRNA subunits. In the case of muscle tissue, four differentially expressed sequences were recorded which codified for proteins associated to the immune system response, as well as cell structure and signaling. By means of RT$\mathrm{PCR}$, we also detected differentially expressed chitinase transcripts $(\Delta \mathrm{Ct})$. We observed $\Delta \mathrm{Ct}$ expression values of 0.49 when comparing specimens fed a plant diet to those which underwent a change from plant to an animal diet, while a $\Delta$ Ct value of 0.52 was observed when comparing animals fed with an animal diet to specimens which underwent a change from an animal to a plant protein diet. Differential gene expression was not observed in specimens which did not undergo a change in diet during the experiment.
\end{abstract}

Keywords: Differential display; RT-PCR; Litopenaeus vannamei; Protein diet; Alternative protein sources 


\section{Introduction}

The feed industry related to shrimp farming is of great economic importance as it represents 60 to $80 \%$ of shrimp production costs, with proteins usually accounting for at least a thirdof the compounds found in commercial diets (FAO, 2006). However, the growth of the shrimp farm industry is strongly conditioned by the availability and quality of proteins produced from aquatic organisms, and effluents from shrimp farms have been shown to produce relevant environmental impacts. Current feeding methods take advantage of shrimp omnivorous habits by incorporating plant-based ingredients to their diet as an alternative source of protein which, in addition, may contribute to the reduction in environmental impacts derived from this industry (Kanazawa, 1989). As a result, current research is now focused on shrimp responses (e.g., metabolic, physiological) to phytochemical components present in the diet, as well as the indentification of genes responsible for such changes at the molecular level. Results from these studies are beginning to shed some light on how specific nutrients and compounds produce specific changes at the molecular level, which in turn cause metabolic and physiological changes in shrimp. This information has triggered rapid advances in the shrimp feeding industry (Gillies and Faha, 2003; Match et al., 2005), which is now beginning to rely on an emergent research field known as "nutrigenomics" which seeks to understand how different components of the diet influence molecular mechanisms which in turn determine shrimp physiology, and in this way find strategies to optimize nutrient use and increase the quality of the final product (Bonneau and Laarveld, 1999; Paoloni-Giacobino et al., 2003).

Recent studies have reported that plant protein-based diets can cause signficant changes in gene expression in fish (Gómez, 2007), because they are rich in bioactive compounds such as phytochemical agents, antioxidants, polyunsaturated fatty acids (PUFAs), vitamins and vitamin precursors. Nonetheless, genes that codify for proteins involved in metabolic pathways which are activated depending on the diet's protein source have not received much attention in shrimp. The same holds true for research on the physiological implications of changes in gene expression levels due to shifts in dietary protein source. The present work represents an explorative attempt to identify differentially expressed genes in shrimp as a result of changes in dietary protein source. Differentially expressed genes under such conditions may be linked to metabolic, physiological and biochemical processes which are relevant in order to achieve an increase in the efficiency and effectiveness of alternative shrimp feeding methods.

\section{Materials and Methods}

\subsection{Biological material and treatments}

A total of 10,000 postlarvae of Litopenaeus vannamei were collected at La Paz, Baja California, Mexico, kept in 400-I tanks and fed with Artemia salina, microalgae and pellets until they reached the postlarva 25 stage (i.e., 25-day old specimens starting from the last metamorphic transformation). Subsequently, 200 juvenile specimens were randomly selected, distributed into separate tanks, and fed three times a day with two different diets for which vitamin, mineral and binder concentrations were held constant. One of the diets included squid flour at $30 \%$ and was named animal diet (A), while the second diet included a mix of potato, soy, wheat gluten and spirulin and was named plant diet (V) (see Table 1). Specimens were then divided into four treatments groups: $V V$ and AA specimens were fed 
with plant or animal protein diets, respectively, throughout the experiment $(54 \mathrm{~d})$; AV specimens were fed with an animal protein diet during the first 36 days, after which they were switched to a plant protein diet until day 54; finally, VA specimens were fed with a plant protein diet the first 36 days, after which they were switched to the animal protein diet up until day 54. A total of 50 specimens were used per treatment group (divided into five tanks per treatment, and 10 specimens per tank). For all treatment groups abiotic conditions including photoperiod (12:12), salinity (28 ppm), temperature, $\mathrm{pH}$, dissolved oxygen and [NH4]+ were held constant. Once specimens reached developmental stage C (following Drach and Tchernigovtzeff, 1967), they were sacrificed, and the hepatopancreas (HP) and muscle tissue (MM) was extracted from each one. Both HP and MM samples were then frozen with liquid nitrogen and stored at $-80^{\circ} \mathrm{C}$ for subsequent molecular analyses. Molecular analyses were performed in triplicate.

\subsection{RNA isolation, differential display (DD) and RT-PCR amplification}

For each treatment group, 10 stage $\mathrm{C}$ specimens were randomly selected for RNA extraction. Total RNA was extracted and homogenized with nitrogen according to commercial Trizol ${ }^{\circledR}$ following the manufacturer's instructions (Invitrogen ${ }^{\circledR}$, Carlsbad, CA). RNA replicates from specimens belonging to each treatment level were mixed which resulted in four samples per treatment group ( $A A, A V, V V$ or $V A$ ), which were used for subsequent differential display (DD) analysis (this was done for both muscle and hepatopancreas samples).

In order to perform the DD analysis, $2 \mathrm{mg}$ of total RNA for each treatment (pooled RNA from all specimens of a given treatment) were incubated with the oligo-dT primer for 60 $\min$ at $42^{\circ} \mathrm{C}$. Subsequently, reverse transcriptase was denaturalized for 5 min at $70^{\circ} \mathrm{C}$. PCR amplification was performed with $1 \mu$ of cDNA using six primer combinations (T1:P1, T2:P3, T4:P3, T7:P3, T1:P6 and T7:P6) from the commercial kit Delta ${ }^{\circ}$ Differential Display (Clontech, Palo Alto, CA), and using the following conditions: $94^{\circ} \mathrm{C}, 5 \mathrm{~min} ; 40^{\circ} \mathrm{C}, 5 \mathrm{~min}$; $68^{\circ} \mathrm{C}, 5 \mathrm{~min}$; one cycle; then $94^{\circ} \mathrm{C}, 2 \mathrm{~min} ; 40^{\circ} \mathrm{C}, 5 \mathrm{~min} ; 68^{\circ} \mathrm{C}, 5 \mathrm{~min}$; two cycles; $94^{\circ} \mathrm{C}, 1$ $\min ; 60^{\circ} \mathrm{C}, 1 \mathrm{~min} ; 68^{\circ} \mathrm{C}, 2 \mathrm{~min} ; 25$ cycles. $5 \mu \mathrm{l}$ of PCR products were fractioned by denaturing electrophoresis in a $5 \%$ polyacrylamide gel with $8 \mathrm{M}$ urea using $0.5 \mathrm{X}$ TBE as buffer, at 70W for $3 \mathrm{~h}$. Gels were dyed with silver nitrate following the protocol of Bassam et al. (1991). Differentially expressed cDNA bands were retrieved, reamplified by PCR (we used the same set of primers used for Differential Display), reamplification binded to plasmid pGEM-T Easy® (Promega) following vector instructions, and then sequenced. Each nucleotide sequence and its corresponding amino acid sequence was compared with sequences from the GenBank database using BLASTX and BLASTN (default search values). Differential gene expression was assessed by comparing the expression pattern of the AA treatment group with the AV group, as well as comparing the $\mathrm{VV}$ group to the VA group.

The following conditions were used for RT-PCR quantification for every $50 \mu$ of reaction: $25.5 \mu \mathrm{l}$ of 2 Q Quantitec SYBR green promega, PCR master MIX, $1 \mu$ of direct primer (Quit rev. 5'-ACCACCAAACACCTCAAC-3'), $1 \mu \mathrm{l}$ of reverse primer (Quit forw. 5'GCTTGGCTACAATGAGATC-3'), and $1 \mu$ of cDNA template. RT-PCR values were also treated by the relative quantification method reported by Livak and Schmittgen (2001), for which we used the cycle threshold $(\mathrm{Ct})$ of actin as a reference (Actine forward: 5'cgcgacctcacagactacct-3'; Act Rev: 5'-gtggtcatctcctgctccaa-3'). The following conditions were used: cycle $1: 9^{\circ} \mathrm{C}$ for $15 \mathrm{~min}, 9^{\circ} \mathrm{C}$ for $30 \mathrm{~s}$; cycle $2: 58^{\circ} \mathrm{C}$ for $50 \mathrm{~s}, 70^{\circ} \mathrm{C}$ for $2 \mathrm{~min}$. 


\section{Results and Discussion}

\subsection{Differential expression of hepatopancreas transcripts}

A total of 52 bands exhibited differential expression due to a change in diet from an animal protein source to a plant protein source (AA vs. AV), while a total of 47 bands showed differential expression for specimens which changed from a plant protein diet to an animal protein diet (VV vs. VA) (Fig. 1). 33\% of these bands were reamplified by PCR, and of these, $45 \%$ were sequenced and 33\% were cloned. Finally, only six bands were sequenced with different sets of primers, one of which was the LV1 sequence obtained using primers $\mathrm{P} 1-\mathrm{T} 1$, which was upregulated due to a change from animal protein to plant protein diet (AA specimens did not exhibit such response) (Table 2). This sequence corresponds to a gene which codifies for a transcription regulation protein involved in the inhibition of the STAT protein(Signal Transduction and Transcription Protein); the STAT protein is a transcription factor of the interferon system which is related to the immune system response, and has been suggested to play a relevant role in resistance against the white spot syndrome virus (WSSV) (Jian-Horng et al., 2007). Based on this result, we suggest that the LV1 sequence is at least partly responsible for an efficient immune system response associated to a change in diet from animal proteins to plant proteins. This finding agrees with a previous study which reported that diet changes enhance an organism's resistance to variation in environmental parameters, as well as improves the immune system response by promoting the agglutination titre of plasma and respiratory burst of haemocytes in Penaeus stylirostris (Chim et al., 2001). Similarly, Supamattaya et al. (2005) also reported a higher resistance to WSSV infection and greater tolerance to a low concentration of dissolved oxygen for black tiger shrimp Penaeus monodon fed with a diet based on commercially available Dunaliella extract.

Another identified sequence which was differentially expressed was fragment G5HAM which corresponds to a segment of RNA messenger Otg14 which codifies for a nonspecific transcription regulatory protein previously reported for the orchid Dendrobium madame (Yu and Goh, 2000). This sequence was also reported for the fruit fly Drosophila melanogaster in a study which looked at the isoforms of a photoreceptor. Unfortunately, these previous findings make it difficult to determine the precise function of this transcription regulation sequence for $L$. vannamei in this study (Yu and Goh, 2000). This protein has shown to work as a transcription activator by binding to protein CDPC, and in this way releases the CAAT promoter box which allows the initiation of RNA synthesis (Table 3).

The sequence corresponding to fragment G420 which was obtained using primers P6-T1 was overexpressed in specimens which underwent a change from animal protein diet to plant protein diet (AV). This sequence showed a high degree of homology with transposase IS630 reported for Listonella anguillarum serovar O2, a gamma proteobacteria belonging to the genus Vibrio which is frequently found during bacteriological water screening of shrimp feeding tanks. This bacterium is found in the digestive tract of shrimp and has the potential to produce clinical manifestations, especially in flock cultures and in intensive systems with high animal densities (Kitting et al., 1987; Rothlisberg, 1988).

To summarize, results showed that a change in diet from AA to AV produced changes in the expression of three genes associated to transcriptional factors and a transposase. The expression of transcription factors suggests the activation of several genes which are probably associated to an immune system response. However, it is still not clear why such 
shift in diet results in the expression of a transposase, thus warranting further studies in order to understand the mechanism behind this response.

We decided to corroborate results from the gene expression analysis by using primers fD1-rD1 which are specific for eubacteria. We detected four differentially expressed fragments of $1600 \mathrm{bp}$, of which we were able to sequence fragment Gab03 which codifies for a $16 \mathrm{~S}$ ribosomal RNA which is similar to that reported for non-cultured bacteria. Symbiotic associations have been reported between seven species of shrimp and bacteria found in their digestive tract (Thompson et al., 2004). This findings point at the importance of studying differential gene expression of microflora in shrimp HP, especially given the benthic habit of shrimp, the diet changes they undergo throughout their development, as well as their partially detritivorous feeding habits (Rothlisberg, 1988). Sequences LV13 and G422 (GenBanK 1 and GenBank 2, respectively) which were induced due to a change in diet from plant protein to animal protein (absent for specimens which changed from animal protein diet to plant diet) exhibited a high degree of homology with two different regions of a single gene reported for $L$. vannamei which codifies for chitinase ( $\mathrm{N}$-acetyl D-glucosaminidase), an enzyme which hydrolyzes chitin by breaking the 1-4 bond of the chitin polymer. Chitin is an important protein found in the cellular wall of fungi, as well as in the exoskeleton of arthropods (Fox, 1993). These two regions were different in size and were detected using different primers. Because chitinase is commonly found in bacteria, some authors suggest that this enzyme has an exogenous origin in peneids (Kitting et al., 1987). However, recent studies have shown an endogenous production of this protein under deficient feeding conditions for several shrimp species (Fox, 1993). In arthropods, chitinase has been associated with nutrient digestion, rupture of the exoskeleton prior to moulting, as well as with the regulation of the physical properties of the peritrophic membrane. For instance, Tan et al. (2000) showed that this enzyme was differentially expressed during moulting of Penaeus monodon shrimp. Our results indicated an increase in chitinase mRNAs when the diet was changed from AA to AV and this was probably related to a metabolic response aimed at digesting complex and diverse carbohydrates. Based on these findings, we propose a direct effect of a diet change on the expression of specific genes, among which is the gene which codifies for chitinase which is involved principally in food digestion.

\subsection{Differential expression of muscle transcripts}

Four differentially expressed bands were identified in muscle tissue samples (Table 4). Clone G214AM, which corresponds to an intergenic region that codifies for an interferon promoter protein (CIG64), accumulated in samples belonging to the VA treatment. Protein CIG64 is a fundamental component of the immune system response in vertebrates and invertebrates and is differentially expressed in response to several stimuli (Roux et al., 2003; Mudagandur and Yuanan, 2008). Although immune system responses in invertebrates are not yet fully understood, recent studies have identified interferon-type proteins which are apparently related to invertebrate host immune responses to pathogen infection (Andersen et al., 2005; Mudagandur and Yuanan, 2008). The observed increase in transcript levels for protein G214AM due to a diet shift from plant protein to animal protein suggests that nutritional changes may have the potential to modify the immune response of juvenile shrimp.

Another amino acid sequence found in $L$. vannamei muscle tissue corresponded to clone G425 and exhibited 100\% homology with a region of the gene which codifies for the heavy chain of myosin. Such sequence was up-regulated in response to a change in diet from plant protein to animal protein and was identified using the primer combination P5-T7. 
Some authors suggest that feeding methods used in aquaculture are the most common way of controlling meat quality because of the well-recognized influence of diet on muscle composition (Andersen et al., 2005). The observed mRNA sequence of this fragment showed a high degree of similarity to that reported in a previous study for the variant $C$ of mRNA which corrresponds to the heavy chain CG17927-RC of myosin in Drosophila melanogaster (see Table 4) (Hoskins et al., 2007). In relation to these results, Andersen (2005) reported metabolic changes in pigs due to low levels of vitamin E which disabled protein quinase I which in turn inhibited catalysis for phosphorylation and inactivated glycogen synthase, thus limiting glycogen synthesis (Roux et al., 2003). Although this mechanism has generated some debate, there are currently no other competing hypothesis to explain why high and sustained levels of vitamin E appear to be necessary for the glycogen metabolism which determines meat quality (Robin et al., 1992). Because plant protein-based diets usually contain spirulina algae which exhibit a high content of vitamin $\mathrm{E}$, diet changes have been proposed as an important factor driving the differential expression of mRNAs in shrimp muscle tissue (Robin et al., 1992).

\subsection{Quantification of mRNA expression levels based on RT-PCR}

To corroborate differential gene expression results we used chitinase to perform semiquantitative RT-PCR and employed the transcript of actin as an endogenous reference. Chitinase mRNA expression levels did not show changes relative to actin when specimens were fed a constant diet (VV or AA). However, chitinase expression levels increased when specimens were subject to a change in diet from an animal to plant protein source $(\Delta \mathrm{Ct}=$ 0.52). Interestingly, transcript levels also increased for specimens which underwent a change from a plant protein diet to an animal protein diet VA $(\Delta \mathrm{Ct}=0.49)$. These findings agree with results based on the differential display technique, and strongly suggest that a change in diet protein source induces the expression of chitinase in L. vannamei.

Research on plant protein-based diet effects on gene expression, metabolism and overall health status has been conducted for other shrimp species such as Penaeus monodon (Supamattaya et al., 2005), as well as in humans (Corthésy-Theulaz et al., 2005). Finally, Piñero (2003) looked at the effect of lipids as an energy source and inducer of gene expression in intestine cells of tilapia.

\section{Conclusions}

Results from this study indicated that a shift in diet from an animal protein source to plant protein source and viceversa can cause changes in the expression of several genes in $L$. vannamei, some of which are up-regulated while others are down-regulated. Such findings are evidence that diet protein source can modify the genetic expression in hepatopancreas and muscle tissue of juvenile specimens of $L$. vannamei, and that such changes may be related to metabolic and physiological adjustments to assimilate the type of food provided. Our results provide an opportunity to identify relevant molecular markers associated with the nutritional response of white shrimp, as well as other species of commercial value. On the other hand, sequences not found in NCBI databases may be used to scan CDNA banks and monitor transcript levels by means of northern blot or nuclease protection assays.

The information generated from studies such as the present work is essential to predict physiological or metabolic changes in shrimp as a result of diet modifications and to design appropriate diet modifications. A priori knowledge on such changes may serve to improve 
shrimp feed technologies, as well as to improve production output, animal health and meat quality. It is also important to mention that diet changes in this study also triggered gene expression changes for two types of bacteria present in the digestive tract of shrimp, one of which belonged to the genus Vibrio and has been previously reported in other studies (Planas et al., 2005). This result is highly relevant as current methods are trying to take advantage of symbiotic microbiota to improve the effectiveness of commercial nutrition technologies.

\section{Acknowledgements}

This study was financed by the Direccion General de Asuntos del Personal Academico through the project Programa de Apoyo a Proyectos de Investigacion e Innovacion Tecnologica (IN216406-3), as well as by the Consejo Nacional de Ciencia y Tecnologia (49406). We also thank L. Abdala-Roberts for the translation of this manuscript.

\section{References}

Alberti, M., Kausch, U., Haindl, S. and Seifert, M. 2005. Gene expression analysis for exposure to estrogenic substances. Acta Hydrochim. Hydrobiol. 33:38-44

Altschul, S., Gish, W., Millar, W., Myers, E. W. 1990. Alignement search tool. J. Mol. Biol. 215:403-10.

Andersen, H., Oksbjerg, N., Young, J. and Therkildsen, J. 2005. Feeding and meat quality -a future approach. Meat Science 70:543-554.

Bassam, B. J., Caetano-Anolles, G., and Gresshoff, P. M. 1991. Fast and sensitive silver staining of DNA in polyacrylamide gels. Anal. Biochem. 196:80-3.

Bonneau, M., and Laarveld, B. 1999. Biotechnology in animal nutrition, physiology and health. Livestock Production Science 59:223-241.

Drach, P., and Tchernigovtzeff, C. 1967. Sur la méthode de determination des stades d'intermue et son application générale aux crustacés. Vie et Milieu, Sér. A Biolog. Mar. 8:595-610.

Ewart, K., Belanger, V., Williams, J., Karkach, T., Penny, S., Tosí, S. Richards, R. and Douglas, S. 2005. Identification of genes differentially expressed in Atlantic salmon (Salmo saladar) in response to infection by Aeromonas salmonicida using cDNA microarray technology. Dev. Comp. Inmmunol. 29:333-347.

FAO. 2006. Fisheries technical paper. State of world aquaculture. 500-56.

Fox, C. J. 1993. The effect of dietary chitin on the growth, survival and chitinase levels in the digestive gland of juvenile Penaeus monodon. Aquaculture 109:39-49.

Gillies, J. P., and Faha, P. D. 2003. Nutrigenomics: The Rubicon of molecular nutrition. Journal of the American Dietetic Association 103:s50-s55.

Gómez, A. A. 2007. Nutrigenómica y Nutrigenética. Ámbito Farmacéutico, Nutrición 25:7886.

Hoskins, R.A., Carlson, J.W., Kennedy, C. 2007. Sequence finishing and mapping of Drosophila melanogaster heterochromatin. Science, 316:1625-1628.

Jiang-Ping, C., Sheik, T., Zhu, H. 1997. Use of dfferential display analysis to asses the effect of human cytomegalovirus infection on the accumulation of cellular rnasinduction of interferon-responsive rnas. Proceedings of the National Academy of Sciences of the USA 94:985-900. 
Jin-Lu, W., Jian-Horn, L., and Chin-Chin, C. 2007. Comparative analysis of differentialy expressed genes in normal and white spot syndrome virus-infected Penaeus monodon. FEBS Letters 551:53-57.

Kanazawa, A. 1989. Protein requeriments of penaeid shrimp. Advances in Tropical Aquaculture 9:262-270.

Kitting, C.L., Dempsey, A.C. 1987. Characteristics of bacteria isolated from penaeid shrimp. Crustaceana 52:90-94.

Kono, M., Wilder, M. N., Matsui, T., Furukawa, K., Koga, D., and Aida, K. 1995. Chitinolytic enzyme activities in the hepatopancreas, tail fan and hemolymph of kuruma shrimp Penaeus japonicus during the molt cycle. Fisheries Sci. 61:727-728.

Livak, K., and Schmittgen, T. 2001. Analysis of Relative Gene Expression Data Using Real-Time Quantitative PCR and the 2- ${ }^{\Delta \triangle C t}$ Method. METHODS 25:402-408.

Mahoney, C. W., and Azzi, A. 1998. Vitamin e inhibits protein kinase c activity. Biochemical and Biophysical Research Communications 154: 694-697.

Mudagandur, S. S., and Yuanan, L. 2008. Application of nucleic-acid-based therapeutics for viral infections in shrimp aquaculture. Marine Biotechnology 36:5652-5659.

Match, M. D., Wahli, W., and Williamson, G. 2005. Nutrigenomics and nutrigenetics: the emerging faces of nutriton. The FASEB Journal 19:1602-1614.

Paoloni-Giacobino, A., Grimble, R., and Richard, C. 2003. Genetics and Nutrition. Clinical Nutrition 5:429-435.

Piñero, C., Barros-Velázquez, J., Vázquez, J:, Figueras, A., and Gallardo, J. 2003. Proteomics as a tool for investigation of seafood and other marine products. J. Proteome Res. 2:127-135.

Planas, M., Pérez-Lorenzo, M., Vázquez, L., and Pintado, J. 2005. A model for experimental infections with Vibrio (Listonella) anguillarum in first feeding turbot (Scophthalmus maximus L.) larvae under hatchery conditions. Aquaculture 250:232-243.

Robin, L., Thakur, M. L., and Srivastava, U. S. 1992. Turnover cyclic adenosine 5monophosphate is elevated in skeletal muscle of vitamin e-deficient rabbits. Journal of Nutrition 122:1935-1941.

Rothlisberg, P. C. 1988. Aspects of penaeid biology and ecology of relevance to aquaculture: a review. Aquaculture 164:49-65.

Roux, M. M., Dhar, A. K., and Dettori, A. 2003. Identification of differentially expressed genes in shrimp (Penaeus stylirostris) infected with white syndrome virus by cDNA microarrays. Archives of Virology 148:2381-2396.

Siok, H., Bernard, M., Degnan, Sigrid, A., and Lehnert, A. 2000. The Penaeus monodon Chitinase 1 Gene is differentially expressed in the hepatopancreas during the molt cycle. Mar. Biotechnol. 2:126-135

Thompson, F., Rodríguez, J., and Gullian, M. 2004. Selection of probiotic bacteria and study of their immunostimulatory effect in Penaeus vannamei. Aquaculture 233:1-14.

Yu, H., and Goh, C. J., 2000. Identification and caracterization of the three orchid madsbox genes of the ap1/agl9 subfamily during floral transition. Plant Physiology 123:13251336.

http://www.sciencedirect.com/science?_ob=ArticleURL\&_udi=B6WFN-4KJ6KMM-

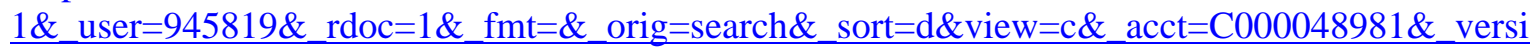

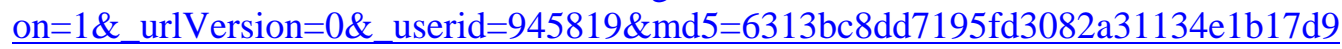




\section{Tables}

Table 1. Formula composition of the diets used for L. vannamei in the present study.

\begin{tabular}{|c|c|c|}
\hline 4.1.1. Ingredients & Animal protein diet & 4.1.2. Plant protein die \\
\hline $\begin{array}{l}\text { Soluble fish protein } \\
\text { concentrate }^{1}\end{array}$ & $16 \%$ & $9 \%$ \\
\hline Soybean paste ${ }^{2}$ & $15 \%$ & \\
\hline Wheat meal & $14 \%$ & $10,5 \%$ \\
\hline Dried Squid & $30 \%$ & \\
\hline Concentrated soybean protein & & $30 \%$ \\
\hline Concentrated starch & & $5 \%$ \\
\hline Wheat gluten & & $9 \%$ \\
\hline Spirulin & & $9 \%$ \\
\hline Cod-liver oil & $3.5 \%$ & $5 \%$ \\
\hline Soy Lecithin & $2 \%$ & $2 \%$ \\
\hline Colesterol & $0.5 \%$ & $0.5 \%$ \\
\hline Starch & $14.5 \%$ & $16.5 \%$ \\
\hline Vitamin C & $0.0286 \%$ & $0.45 \%$ \\
\hline Mineral and Vitamin premix ${ }^{3}$ & $2 \%$ & $1 \%$ \\
\hline Agglutinin & $1 \%$ & $1 \%$ \\
\hline Zeolite (digestion marker) & $1.5 \%$ & $1.5 \%$ \\
\hline Total & $100 \%$ & $100 \%$ \\
\hline
\end{tabular}

(1) $70 \%$ of protein, Apligén S.A, México, (2) $48 \%$ protein, Nutrimin, S.A. México, (3) DMS, Nutritional Products, México

Table 2. Fragment sequences differentially expressed in L. vannemei and their probable function. We indicate the source from which the genes were obtained, the differential expression identified and primers used. Nomenclature is as follows: $\mathrm{DE}=$ Differential expression; HP= hepatopancreas; $\mathrm{MM}=$ =muscular tissue; $\mathrm{I}=$ induced; $\mathrm{A}=$ =absent; $\mathrm{OE}=$ Overexpressed gene; and $\mathrm{P}=$ =present.

\begin{tabular}{|l|l|l|l|l|l|}
\hline ID & PPCH & Tissue & Diet & DE & Primers \\
\hline LV13 & Chitinase of L. vannamei & hp & VA & a & P1-T1 \\
\hline LV1 & STAT protein Inhibitor & hp & AV & a & P1-T1 \\
\hline Gab03 & Ungrowable bacteria & $\mathrm{hp}$ & VA & $\mathrm{p}$ & fD1-rD1 \\
\hline G422 & Chitinase RNAm & $\mathrm{hp}$ & VA & a & P6-T1 \\
\hline G420 & Listonella anguillarum Transposase IS630 & $\mathrm{hp}$ & $\mathrm{AV}$ & $\mathrm{i}$ & P6-T1 \\
\hline G5HAM & mRNA of Promoter protein Otg14 & $\mathrm{hp}$ & VA & i & P3-T4 \\
\hline G214AM & Interpheron promoter & $\mathrm{mm}$ & VA & oe & P5-T7 \\
\hline G425 & Heavy chain myosine & $\mathrm{mm}$ & VA & oe & P5-T6 \\
\hline GCBAM & Kinase from casein & $\mathrm{mm}$ & AV & oe & P6-T7 \\
\hline G243AM & Not reported & $\mathrm{mm}$ & VA & i & P3-T7 \\
\hline
\end{tabular}


Table 3. Identity of amino acid sequences deduced from cDNA bands which displayed differential expression in L. vannamei hepatopancreas.

\begin{tabular}{|c|l|c|c|c|c|c|c|c|}
\hline \multicolumn{1}{|c|}{ ID } & \multicolumn{1}{|c|}{ PPCH } & Diet & ED & Primers & $\begin{array}{c}\text { Accession } \\
\text { number }\end{array}$ & E Value & $\begin{array}{c}\text { Identity } \\
\text { (\%) }\end{array}$ & $\begin{array}{c}\text { Sequence } \\
\text { length (bp) }\end{array}$ \\
\hline LV13 & $\begin{array}{l}\text { Chitinase of } \\
\text { L. vannamei }\end{array}$ & VA & i & P1-T1 & EU381118.1 & $7.00 E-176$ & 100 & 542 \\
\hline LV1 & $\begin{array}{l}\text { STAT protein } \\
\text { inhibitor }\end{array}$ & AV & r & P1-T1 & DQ858917 & $6.00 E-110$ & 99 & 433 \\
\hline Gab03 & $\begin{array}{l}\text { Ungrowable } \\
\text { bacteria }\end{array}$ & VA & $\mathrm{d}$ & fD1-rD1 & EF446186.1 & $3.00 E-72$ & 94 & 277 \\
\hline G422 & $\begin{array}{l}\text { Chitinase } \\
\text { mRNA }\end{array}$ & VA & $\mathrm{i}$ & P6-T1 & EU381118.1 & $5.00 E-46$ & 96 & 115 \\
\hline G420 & $\begin{array}{l}\text { L. } \\
\text { anguillarum } \\
\text { transposase } \\
\text { IS630 }\end{array}$ & AV & $\mathrm{i}$ & P6-T1 & CAL47051 & $3.00 \mathrm{E}-04$ & 47.8 & 146 \\
\hline G5HAM & $\begin{array}{l}\text { mRNA of } \\
\text { Promoter } \\
\text { protein Otg14 }\end{array}$ & VA & $\mathrm{i}$ & P3-T4 & AF107591 & $4.00 \mathrm{E}-05$ & 100 & 56 \\
\hline
\end{tabular}

$\mathrm{PPCH}=$ Protein probable of homologue combination; $\mathrm{ED}=$ differential expression; i=induced; $r=$ repressed; se=up regulated; $d=$ reduced.

Table 4. Identity of amino acid sequences deduced from cDNA bands which displayed differential expression in L. vannamei muscle tissue.

\begin{tabular}{|l|l|c|c|c|c|c|c|c|}
\hline \multicolumn{1}{|c|}{ ID } & \multicolumn{1}{|c|}{ PPCH } & Diet & ED & Primers & $\begin{array}{c}\text { Accession } \\
\text { number }\end{array}$ & E Value & $\begin{array}{c}\text { Identity } \\
\text { (\%) }\end{array}$ & $\begin{array}{c}\text { Sequence } \\
\text { length (bp) }\end{array}$ \\
\hline G214AM & $\begin{array}{l}\text { Interpheron } \\
\text { promoter }\end{array}$ & VA & se & P5-T7 & AF026945.1 & $9.00 \mathrm{E}-05$ & $100 \%$ & 59 \\
\hline G425 & $\begin{array}{l}\text { Heavy chain } \\
\text { myosine }\end{array}$ & VA & se & P5-T6 & AF107585.1 & $3.00 \mathrm{E}-04$ & $100 \%$ & 115 \\
\hline GCBAM & $\begin{array}{l}\text { Kinase from } \\
\text { casein }\end{array}$ & VA & i & P6-T7 & AF107592.1 & $4.00 \mathrm{E}-04$ & $100 \%$ & 158 \\
\hline G243AM & Not reported & VA & i & P3-T7 & & & & 403 \\
\hline
\end{tabular}

$\mathrm{PPCH}=$ Protein probable of homologue combination; $\mathrm{ED}=$ differential expression; i=induced; $r=$ repressed; se=up-regulated; $d=$ =reduced. 


\section{Figure}

Figure 1. Image of a Differential Display (DD) electrophoresis gel from hepatopancreas (HP) tissue of $L$. vannamei juveniles from treatment groups AA (lanes 3 and 4), AV (lanes 5 and 6), VV (lanes 7and 8), VA (lanes 9 and 10). Lane 1 corresponds to a 100 bp marker. The horizontal red lines show the total differential bands.

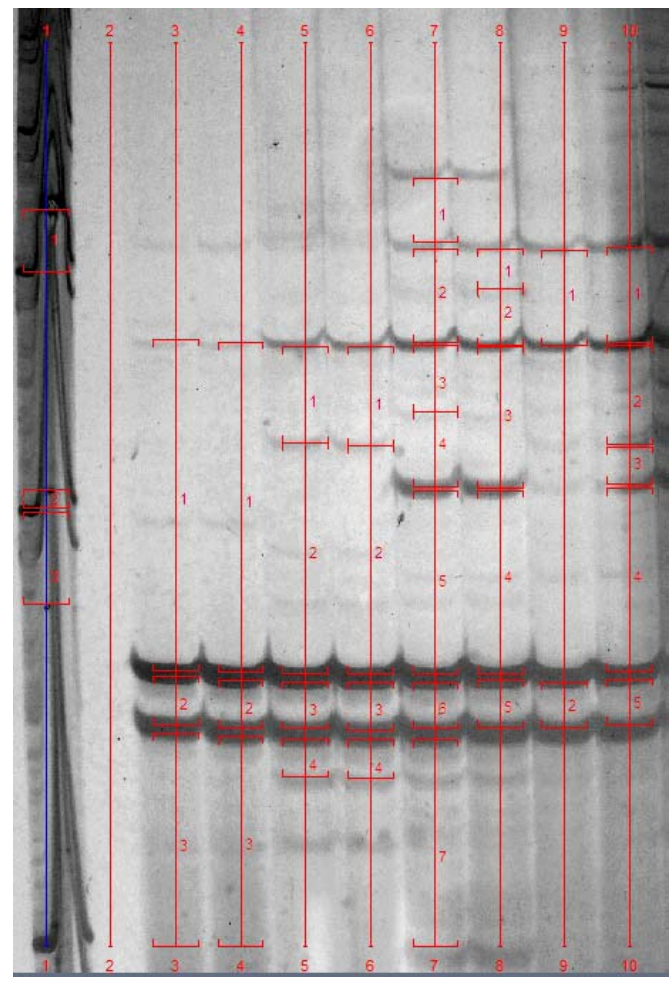

